\title{
Bibliopolitics: The History of Notation and the Birth of the Citational Academic Subject
}

\author{
MATTHEW SHARPE \& KIRK TURNER \\ Deakin University, Australia
}

\begin{abstract}
The paper builds upon a growing body of critical research on the proliferating use of bibliometrics as a means to evaluate academic research, but brings to it a specifically Foucauldian, genealogical approach. The paper has three parts. Part 1 situates bibliometrics as a new technology of neoliberal, biopolitical governmentality, alongside the host of other 'metrics' (led by biometrics) that have emerged in the last two decades. Part 2 analyses bibliometrics' antecedents in prior notational practices in the Western heritage, highlighting how forms of noting have almost always had political valences tied to projects of control or subversion. Part 3 then delineates the specific features of bibliometrics as a new form of notation, highlighting the latest forms of academic subjectivity bibliometrics suppose and increasingly are summoning into being.
\end{abstract}

Keywords: Bibliometrics, neoliberalism, biopower, notation, metric power.

Bibliometrics, to all appearances the most innocuous of innovations, is "the application of mathematics and statistical methods to books and other media of communication."1 One might not think that this new technology could move worlds, or reshape entire regimes of academic practice. The commensurating premise that enables the mathematics to happen is that a citation of some chapter, article or book, any citation, represents an 'endorsement' of that text. Thus, "[t]he importance of an idea is measured by the number of citations received by the document(s) in which it is embedded." 2 This premise given, the 'prestige' or 'quality' of an article in any discipline whatsoever can be calculated, and ranked against all others, according to the number of citation-endorsements

\footnotetext{
${ }^{1}$ Alan Pritchard, "Statistical Bibliography or Bibliometrics," Journal of Documentation 25:4 (1969), 348.

${ }^{2}$ Christine L. Borgman, "Editor's Introduction," in Scholarly Communications and Bibliometrics, ed. Christine L. Borgman (1990), 19.
} 
and (in more recent measures) the prestige of the journals in which the 'donor-citations' are found.

The spread of this bibliometrical technology has been remarkable. Whereas the Science Citation Index began publication in $1961,{ }^{3}$ it was only with the advent of the internet after 1998 that bibliometrics came of age. ${ }^{4}$ Automatic web-enabled citation indexing was introduced in 1998 with CiteSeer, followed soon afterwards by Google Scholar. These pioneers have been followed by a host of competing citation-counting web-platforms like SCImago, each enabled by automatic algorithmic extraction and grouping of citations from millions of digitalised documents. ${ }^{5}$ In 2003, the Shanghai Academic Ranking of World Universities (ARWU) was born, assigning 20\% of a university's putative value to quality of research, measured using the Science Citation Index Expanded and Social Science Citation Index to rank the research productions of its staff. In 2004, the QS World University Rankings began to use citations data, collected over five-year periods, from Thomson (since 2007 they have applied Scopus, owned by internet publishing giant, Elsevier), likewise to assign 20\% of total university scores. Since 2010, the Times Higher Education World University Rankings has assigned some $32.5 \%$ of a university's score to citation metrics, this time drawn from Thomson Reuters Web of Science.

The rapid proliferation of bibliometrics, then, is far from being as null as its apparently seamless acceptance into academics' lifeworlds might make it seem. By way of these global university rankings, bibliometrics have fast assumed a prominent place in how tertiary institutions are evaluated, governed, staffed and marketed. ${ }^{6}$ Whether academics like it or not - and however great the disparity between this new numerical dispensation and older intellectual norms surely is - scholars and their written productions are today compared, counted, rated and ranked by these new technologies in ways almost unimaginable even 25 years ago. Bibliometrical citation counts, as Audrey Baneyx notes, are "considered in grants, hiring, and tenure decisions by laboratories, institutions, and governments. For many reasons, researchers may want to demonstrate the impact of their work, and citation analysis is one, albeit controversial, way of doing so."7

There is a growing critical literature that has emerged in the wake of the rise and rise of bibliometrics. Scholars have questioned the manifold, tendentious assumptions that

\footnotetext{
${ }^{3}$ See, for the evolution of citation indexing, Robert Hauptman, Documentation: A History and Critique of Attribution, Commentary, Glosses, Marginalia, Notes, Bibliographies, Works-Cited Lists, and Citation Indexing and Analysis (2008), 189-191.

${ }^{4}$ On this history, see Roger Burrows, "Living with the H-Index," The Sociological Review 60:2 (2012), 358361.

${ }^{5}$ See ibid., 358-359, on what Burrows calls "the moment of the metrics," which he dates (focusing on the United Kingdom) as somewhere between 1996 and 2001 based on Research Assessment Exercises (RAEs).

${ }^{6}$ See esp., William Locke, "The Institutionalization of Rankings: Managing Status Anxiety in an Increasingly Marketized Environment," in University Rankings: Theoretical Basis, Methodology and Impacts on Global Higher Education, eds. Jung C. Shin, Robert K. Toutkoushian and Ulrich Teichler (2011); "Living with the HIndex," 367-368; and, for a particular national case study, William Y.W. Lo, University Rankings: Implications for Higher Education in Taiwan (2014).

${ }_{7}$ Audrey Baneyx, "'Publish or Perish' as Citation Metrics Used to Analyze Scientific Output in the Humanities: International Case Studies in Economics, Geography, Social Sciences, Philosophy, and History," Archivum Immunologiae et Therapiae Experimentalis 56:6 (2008), 369.
} 
underlie the commensurating premises of bibliometrical citation counting: amongst them, that journals, which have migrated more rapidly online, are necessarily superior venues for academic publications than books or chapters; that all disciplines (arts, sciences, business, medicine...) could or should have the same citational cultures; that peer-reviewed publication 'in top journals' is the only or most valuable aspect of what academics do; and that all citations, even highly critical ones, are effectively equal as putative tokens of esteem. ${ }^{8}$

The following paper builds upon this research and the several international manifestoes that have appeared calling for critical caution and intelligent discretion in the use of these new bibliometric technologies. Nevertheless, it wants to bring to this literature a specifically Foucauldian approach and set of concerns. In what follows, we want to carry forwards the project that Michel Foucault described as writing "the history of the present." It will be a question of using the genealogical work of Foucault and thinkers influenced by him as the means to understand bibliometrics as a new technology of neoliberal governmentality; grasping how its various features and 'affordances' differ from those of prior notational practices in the Western heritage; and delineating the new forms of academic subjectivity bibliometrics supposes and increasingly summons into being.

The paper has three parts. In Part 1, we situate bibliometrics as a new technology for auditing and disciplining research conduct within two convergent histories. The first is the history of the biopolitical, quantitative technologies characterising forms of modern governmentality which culminate in today's 'metric explosion,' as it might be termed. The second history is that of the more recent technologies for governing the unemployed, deviant, and other recipients of public moneys that have emerged in 'neoliberal' or 'advanced liberal' regimes. In Part 2, we then situate the emergence of bibliometrics in light of the long and, as we will see, in fact always-highly-political history of Western note-taking in its different lineages, looking back to scribal marginalia and ancient forms of "self-writing." As per Figure 1 below, Part 3 brings together the converging genealogical work of the opening two parts. It analytically draws out the singular features of bibliometrics, in systematic comparison with the West's previous forms of notation, their

\footnotetext{
${ }^{8}$ For a small sample of this literature, see Baneyx, "Publish or Perish'"; Locke, "The Institutionalization of Rankings"; Colin Macilwain, "Halt the Avalanche of Performance Metrics," Nature 500:7462 (14 August 2013), 255; Diana Hicks, Paul Wouters, Ludo Waltman, Sarah de Rijcke and Ismael Rafols, "Bibliometrics: The Leiden Manifesto for Research Metrics," Nature 520:7548 (22 April 2015), 429-431; Julia Lane, "Let's Make Science Metrics More Scientific," Nature 464:1267 (25 March 2010), 488-489; Anne-Wil Harzing, "Citation Analysis Across Disciplines: The Impact of Different Data Sources and Citation Metrics," Harzing.com: Research in International Management; Phil Jones, "Altmetrics and Research Assessment: How Not to Let History Repeat Itself," The Scholarly Kitchen (1 September 2015); Maarten van Wesel, "Evaluation by Citation: Trends in Publication Behaviour, Evaluation Criteria, and the Striving for High Impact Publications," Science and Engineering Ethics 22:1 (2016), 199-225; "Poor Citation Practices Are a Form of Academic SelfHarm in the Humanities and Social Sciences," Medium.com; Björn Brembs, Katherine Button and Marcus Munafò, "Deep Impact: Unintended Consequences of Journal Rank," Frontiers in Human Neuroscience (24 June 2013); Peter Weingart and Sabine Maasen, "Elite Though Rankings - The Emergence of the Enterprising University," in The Changing Governance of the Sciences: The Advent of Research Evaluation Systems, eds. Richard Whitley and Jochen Gläser (2007), 75-99; "Living with the H-Index," esp. 361-362.
} 
subjects, objects, addressees, means and ends (Part 2), and in connection with its neoliberal credentials (Part 1). The greatest danger of these new, increasingly omniscient and omni-visible technologies, hitherto under-recognised in the literature, the argument would suggest, lies in how they shape forms of subjectivity increasingly unable to see 'outside' and thus critique the avalanche of quantitative measures that are promising to tell scholars the truth about themselves and their work.

Part 1:

Biopower: disciplines, population sciences

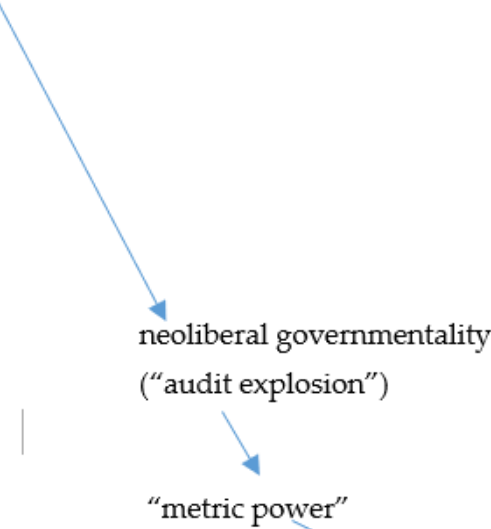

Part 3: Bibliometrics
Part 2:

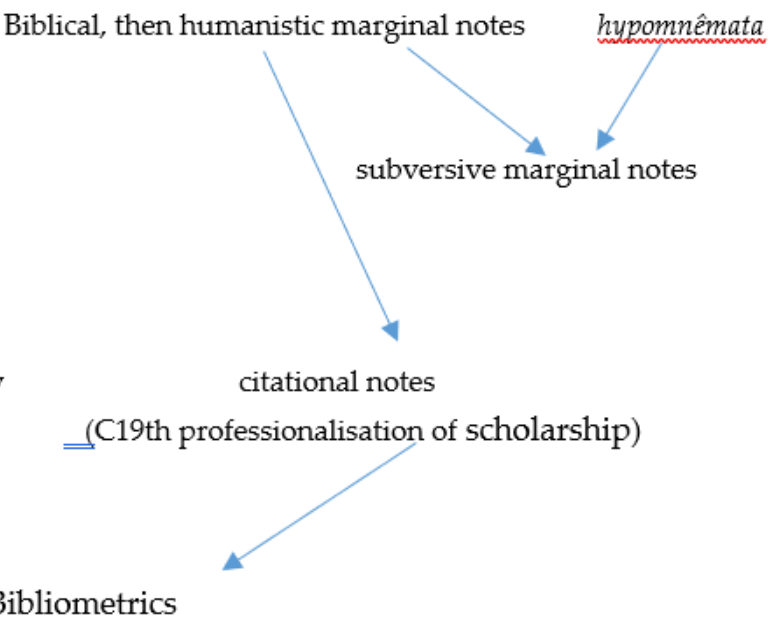

Figure 1: The Argument Pictured: The Convergent Genealogies of Bibliometrics

\section{Part 1: Metric Power and Neoliberal Governmentality}

We are currently living in a highly advanced phase of tracking and extracting quantitative data from myriad forms of human activity. Bibliometrics is only one manifestation of this wider phenomenon: what has been called "a culture of metrics and also a cultural metrics...both a cultural interest in numbers and culture that is shaped and populated with numbers." ${ }^{9}$ With the development of increasingly sophisticated computer-based technologies, combined with the shrinking of digital storage spaces, a social conjuncture has emerged in which the coding of units of information - from website preferences to social media participation; from employment history to one's tax situation - has on the one hand streamlined earlier, more cumbersome, lengthy or environmentally harmful practices of collecting and maintaining records. On the other hand, it has created an increasingly complicated network of data storage, miners, owners and (third-party) suppliers, as well as new forms of power and subjectivation: what David Beer has dubbed "metric power." 10

At issue here is more than government-mandated information streams (e.g. census, social security or health-related data), or even the sneaky, contractually 'agreed' tracking enabled by the internet and mobile apps. With the advent of the digitalised iPhone in particular, subjects are now constantly providing data about themselves - down to their very movements, number of steps walked, calories consumed, etc. - whether knowingly

\footnotetext{
${ }^{9}$ David Beer, Metric Power (2016), 145.

${ }^{10}$ I.e. the title of Beer, Metric Power.
} 
or in a disavowed form (i.e., "I know fully well that others have access to this information, but I don't need to consider the full implications of this").

For instance, there is the provision of information about how our bodies are functioning: the province of "biometrics." A team from Microsoft Research, in conjunction with MIT and SUNY, recently attempted to put the rise of self-tracking biometrical devices into historical perspective. Their study looks backwards to the weight scale of the late $19^{\text {th }}$ century, and forwards to the wristband or clip-on tracker of today. ${ }^{11}$ They note how there is indeed a long lineage of a "drive toward physical quantification and, specifically, a connection between external measurement and self-knowledge" which is peaking, rather than newly emerging today. ${ }^{12}$ The measurement of one's weight, for instance, became commonplace, beginning in doctor's offices, around the beginning of the $20^{\text {th }}$ century. The invention of the penny scale, available on the streets of major industrialised cities, gave general populations the opportunity to utilise the technology cheaply whenever they so desired. Then, a growing acceptance of the putative 'necessity' for heightening forms of self-knowledge heralded the home scale and, most recently, wearable digital devices like watches which promise a further leap forwards in the quantity and convenience of information available to subjects.

Today's biometrics indeed increasingly monitor the most intimate aspects of "human physiology and...behaviour such as voice recognition, gait, and signature analysis."13 Along with each of these technologies have come discourses positing new ideals of health and normalcy, hence new forms of sometimes obsessional self-management, and, lately, spiralling issues surrounding who has access to what information, for what ends. Indeed, as the authors state: "[ $t$ ]he layers of obfuscation regarding how data are mined are accentuated when comparing the user experience of getting data from wearables versus a weight scale."14

Decisively, that is to say, while the user is receiving, ostensibly satisfied, their own individualised data stream back from the devices, the companies who own and operate the device systems collect and are privy to globalised demographic data unavailable to individuals. In David Beer's words, the metrical data harvested from subjects through

\footnotetext{
${ }^{11}$ Kate Crawford, Jessa Lingel and Tero Karppi, "Our Metrics, Ourselves: A Hundred Years of Selftracking from the Weight Scale to the Wrist Wearable Device," European Journal of Cultural Studies 18:4/5 (2015), 479496. Their principal example is the FitBit, which measures such things as physical ability and number of calories burnt.

12 Ibid., 480.

${ }^{13}$ Elia Zureik and Karen Hindle, "Governance, Security and Technology: The Case of Biometrics," Studies in Political Economy 73:1 (2004), 116.

${ }^{14}$ Crawford, Lingel and Karppi, "Our Metrics, Ourselves," 486. Today's health insurance companies have capitalised on these monitoring technologies, even offering them free to clients in directed campaigns, with a specific view to the reduction of preventable injuries and diseases - which means, for the insurers, a reduction in claims, referrals and cash payouts. Added to this, as Crawford, Lingel and Karppi duly note, is the fact that the "claims to accuracy and reliability of these devices are mythic" (ibid., 490). Not only are the technologies subject to numerous inaccuracies, malfunctions, and the like. The types of knowledge they present also need to be interpreted. In the absence of the kinds of specialised comprehension of physiological processes specific to health professionals, the possible uses of this information, despite claims to the contrary, are at best largely subjective or at worst meaningless.
} 
devices like the iPhone or Apple Watch, "have the scope to appear objective whilst limiting the possibilities for participation and enabling certain power dynamics to thrive."15 When people start using these devices, they enter into a relationship with the digital providers that is inherently asymmetrical. They are providing more data than they receive, and they have little input as to the life of that data, where it is stored, whether it can be deleted, and with whom it is shared, for what ends. ${ }^{16}$ Crawford, Lingel and Karppi are thus right to conclude that the "idea of agency" in and around self-tracking devices "becomes deeply complicated" and imbricated in "complex entanglements of information, consent and privacy." 17 The boundaries of what could any longer be "private' are indeed increasingly rendered opaque.

Weight-tracking technologies proffer merely a single example of the ways that metrics are increasingly omnipresent in our everyday lives, harnessing mechanisms of "identification, categorization (inclusion and exclusion), and...monitoring." 18 The patented increase in the use of these and related metrical and surveillance technologies is directly linked by several authors to the post-9/11 climate of fear. ${ }^{19}$ Sold as means to combat "terrorism, identity theft, and general personal insecurity," these new technologies have increasingly, since 2001, generated concerns surrounding leaks of private information and national security risks. ${ }^{20}$ Yet this advent of "metric power" should also be seen as one, the most recent, chapter in several much longer histories linking forms of human surveillance and quantification with what Foucault famously called "biopower" in the modern West. As we need not belabour here, biopolitics names for Foucault those modern forms of governing that emerged in the $17^{\text {th }}$ and $18^{\text {th }}$ centuries which for the first time "brought life and its mechanisms into the realm of explicit calculations and made knowledge-power an agent of transformation of human life." ${ }^{21}$ On the one hand, modern biopolitics calls upon the disciplines: forms of minute, exacting control over individuals such as surveillance, exercise regimens, rankings and examinations. ${ }^{22}$ On the other hand, biopower from its $17^{\text {th }}$ century inception "gave rise...to comprehensive measures, statistical assessments, and interventions aimed at the entire social body or at groups taken as a whole." ${ }^{23}$ As Pugliese concludes, contemporary metric technologies, from bi-

${ }^{15}$ Metric Power, 47. Here he is discussing Theodore M. Porter's work on 'the rise of statistical thinking' but the thought applies to biometrics.

16 "Our Metrics, Ourselves," 493.

17 Ibid., 494.

${ }^{18}$ Zureik and Hindle, "Governance, Security and Technology," 114.

${ }^{19}$ Indeed, Zureik and Hindle note that the International Biometrics Industry Association sought to capitalise on the terrorist events a mere two weeks later, at a time when the "high-tech and dot-com industries were in a severe economic slump." Ibid., 121.

${ }^{20}$ Ibid., 128.

${ }^{21}$ Michel Foucault, The Will to Knowledge: The History of Sexuality, Vol. 1 [1976] (1998), 143.

${ }^{22}$ On which, see Michel Foucault, Discipline and Punish: The Birth of the Prison [1975] (1995).

${ }^{23}$ Famously, Foucault singles out "demography, the evaluation of the relationship between resources and inhabitants, the constructing of tables analysing wealth and its circulation" as the new 18th-19th century claimants to knowledge constructing a collective subject, the "population" (Foucault, The Will to Knowledge, 140). For the first time, the aggregative powers of this new subject - tendencies to disease or health, rates of 
ometrics to bibliometrics, are indeed "the culmination of a series of anthropometric technologies that can be genealogically traced back to...the historical emergence of biopolitics." 24

With that said, Beer's Metric Power also duly prompts us to comprehend the rise of metrics and big data in the context of more recent, specifically neoliberal or 'advanced liberal,' biopolitical technologies. ${ }^{25}$ In one sense, as Beer suggests, the connection between liberal-capitalist social relations and the kind of quantitative measures for human conduct that metrics promise might seem direct and unchanging. Markets are competitions and competitions must have winners and losers. In order for different parties to be so ranked, some common measure or 'universal equivalent' or 'metric' is required, starting from money itself. Nevertheless, from Foucault's analyses of the German Ordoliberals forwards, ${ }^{26}$ the Foucauldian approach to the nest of ideologemes and governmental strategies known as 'neoliberalism' fundamentally challenges the idea that this 'advanced liberal' governmentality is situated within a continuous, unbroken lineage looking back from Thatcher, Reagan et al. to $18^{\text {th }}$ century political economics and $19^{\text {th }}$ century forms of the 'night-watchman' state. ${ }^{27}$ And understanding how neoliberalism breaks with its liberal predecessors also allows us to see the politico-economic causes behind today's veritable explosion of forms of metrics, reaching from biometrics via bibliometrics even into the sacred groves of academe.

Adam Smith and classical liberals supposed that market exchange was natural and co-primordial with human societies. The best government was then the least government. It is a matter of leaving the market free so human nature can unfold itself, in order to optimise welfare and productivity. Advanced or neoliberal governmentality, by contrast, ${ }^{28}$ looking back to the Ordoliberals, takes it that market relations are actually not 'natural' or 'spontaneous.' Continuing neoliberal rhetoric enjoining the 'small state' and 'deregulation' aside, the post-1979 neoliberal forms of governmentality have been highly activist. ${ }^{29}$ Friedrich Hayek himself, one intellectual inspiration of the new forms of liberalism, was very clear that the market freedom he enjoins is an "artefact" or a "discipline," not something that peoples can be expected to naturally develop:

biological reproduction and economic productivity - could be tallied, charted, comprehended and targeted for interventions by governments. Ibid., 146.

${ }^{24}$ Joseph Pugliese, Biometrics: Bodies, Technologies, Biopolitics (2010), 164.

${ }_{25}$ Metric Power, 7-30.

${ }^{26}$ Michel Foucault, The Birth of Biopolitics: Lectures at the Collège de France, 1978-1979 [2004] (2008), 101-128; cf. for Foucault on neoliberalism more generally Thomas Lemke, “'The Birth of Bio-Politics': Michel Foucault's Lecture at the Collège de France on Neo-Liberal Governmentality," Economy and Society 30:2 (2001), 190-207.

${ }^{27}$ Foucault, The Birth of Biopolitics, 129-158 (11 February 1979).

${ }^{28}$ From here on we shall use 'neoliberalism' to describe the forms of governing that have emerged in the first world since 1979, hostile to the previous social liberal or social democratic compromise.

${ }^{29}$ At the least, they needed to legislatively unwind the direct social welfare, service delivery and tripartite bargaining measures characteristic of the post-war, Keynesian or social democratic dispensation. But see the following for their positive governmental strategies. 
Man has not developed in freedom. The member of the little band to which he had had to stick in order to survive was anything but free. Freedom is an artefact of civilization that released man from the trammels of the small group, the momentary moods of which even the leader had to obey. Freedom was made possible by the gradual evolution of the discipline of civilization which is at the same time the discipline of freedom..$^{30}$

Just so, neoliberalism is best understood not as a project of rolling back the state in order to free pre-existing markets. Following Foucault, it is the recalibration of the state and its institutions in order to actively foster and universalise forms of marketised, competitive behaviour: taking markets, as it were, where markets have never gone before. ${ }^{31}$ It is as if the organised representatives of capital after the 1970s crisis began looking around for new, as-yet-un-commodified arenas of social life to enable the continuing extraction and realisation of surplus value. Terrestrial geography largely conquered, particularly following 1989, they turned to the remaining enclaves within advanced societies as yet relatively insulated from forms of marketised competition: firstly, the interior of organisations, still managed according to more traditional, solidary and hierarchical managerial structures; ${ }^{32}$ and secondly, those institutions of the state involved in directly administering forms of education, health, social welfare and insurance.

Neoliberalism proceeds through an ongoing political struggle against the previous 'social' measures that had characterised the Johnsonian 'Great Society' and comparable forms of social democratic governmentality. "Society does not exist," Margaret Thatcher proclaimed. However that may be, for neoliberalism, the social realm of direct state interventions, benefits and insurance - an "economically and socially costly obstacle to the economic performance upon which it depends" - must be dismantled. ${ }^{33}$ Yet, as Burchell notes, what is to follow is not a setting free of natural markets in welfare, health, penitentiary or education provision, since no such markets have ever existed. Rather:

it becomes a question of constructing the legal, institutional and cultural conditions that will enable an artificial competitive game of entrepreneurial conduct to be played to best effect. For the Chicago economic liberals it is a question of extending a model of rational-economic conduct beyond the economy itself, or generalising it as a principle limiting and rationalising governmental activity. ${ }^{34}$

In particular, neoliberal governmentality sets out to put in place the legal and institutional preconditions which will compel inefficient or an-economic subjects - the unemployed, the unwell, the deviant, or the public sector employee in receipt of a tax-funded

\footnotetext{
${ }^{30}$ Friedrich Hayek, quoted in Mitchell Dean, Governmentality: Power and Rule in Modern Society (1999), 155156.

31 See The Birth of Biopolitics, esp. 129-158 (11 February 1979).

32 See on the managerialist revolution Thomas Frank, One Market Under God: Extreme Capitalism, Market Populism and the End of Economic Democracy (2002).

${ }_{33}$ Graham Burchell, "Liberal Government and Techniques of the Self," in Foucault and Political Reason, eds. Andrew Barry, Thomas Osborne and Nikolas Rose (1996), 27.

${ }^{34}$ Ibid.
} 
salary - to discipline their own conduct to market efficiency. ${ }^{35}$ And the publicly-funded institutions of the state, including the universities, are in their turn to be reshaped according to the same, 'enterprising' neoliberal template. ${ }^{36}$ The implementation of social democratic or welfarist governmental measures, across the different sectors, was the provenance of publicly employed experts, mostly trained within the tertiary social sciences, applying specialised understandings of health, income, education, criminality and social life. From a neoliberal perspective, these 'elites' appear as the quasi-feudal proprietors of rent-yielding, expert enclosures, insulated from political attempts to challenge their discretionary edicts, or healthy economic pressures to optimally perform. ${ }^{37}$ The neoliberal solution, to "breach welfare enclosures," 38 has less involved replacing the old with new, more market-friendly experts, ${ }^{39}$ so much as what can be called a massive transfer of the sanctioned authority previously conferred on the disciplinary experts in the educational, health, social and welfare sectors onto forms of accounting, economics and financial management. The conduct of public sector employees delivering education, welfare or medical services will no longer in neoliberal regimes be a privileged domain regulated by these professionals themselves on the basis of social trust in their intra-professional norms and credentialising. All must instead be subjected to forms of budgetary discipline, auditing (the 1990s thus witnessed what has been called an "audit explosion") and accountancy. ${ }^{40}$ Stuart Burchell et al. thus note how, in the neoliberal

\footnotetext{
${ }^{35}$ The unemployed for instance now become 'jobseekers.' They are subject to active reskilling programs, new forms of ongoing examination of their work-readiness and the sincerity of their search for work, or put to work for the dole. Compelled by threat of sanctions now to choose for themselves from a market of private job-service providers (each themselves competing for new unemployed 'clients' to place), these 'jobseekers' are effectively forced to govern their own conduct as entrepreneurial investors of their own 'human capital' - or to "enterprise themselves," in Rose's felicitous phrase (Nikolas Rose, "Governing 'Advanced' Liberal Democracies," in Foucault and Political Reason, 57). The cause and responsibility of anyone's failure to be gainfully employed is thus from heretofore to be internalised or 'privatised.' No longer the possible signal of governmental failure or societal injustice, it is now a mark of the subject's 'deviance' from marketised norms (see also on neoliberal governance and marketisation of the unemployed, Mitchell Dean, Governmentality, 165-172). They have failed to become successful investors in and of their own 'human capital' - a notion whose importance, we note, Foucault stresses in his lectures on the genealogy of neoliberalism (The Birth of Biopolitics, 215-237).

${ }^{36}$ Rose, “Governing 'Advanced' Liberal Democracies," 54.

${ }^{37}$ Ibid.

${ }^{38}$ Ibid., 55.

${ }^{39}$ Although this measure has also been pursued, in particular, with the creation of privately-funded thinktanks, as a virtual alternative tertiary sector supportive of neoliberal reforms. In conjunction with the direct privatisation of state-owned assets, neoliberal governmentality puts surviving public institutions into artificially engendered competition with sometimes publicly-subsidised private providers of welfare, health, insurance or education, so the market discipline of these quasi-markets can be exercised, and their 'efficiency dividends' be harvested. Our focus here is on how these institutions are managed internally, since this is where metrics take effect.

${ }^{40}$ For the "audit explosion," see Michael Power, The Audit Society: Rituals of Verification (1997), 2-14; cf.

“Governing 'Advanced' Liberal democracies," 54.
} 
period, accounting and auditing measures have become imbricated in almost every aspect of politico-social functioning:41

Accounting data are now used in the derivation and implementation of policies for economic stabilization, price and wage control, the regulation of particular industrial and commercial sectors and the planning of national economic resources in conditions of war and peace and prosperity and depression. ${ }^{42}$

As Rose rejoins concerning the specifically epistemic aspect of this audit explosion, in comparison to the previous forms of 'social' governmentality:

These [accounting, auditing and financial practices] certainly rely upon a claim to truth, but it is one that has a different character from that of the social and human sciences: these 'grey sciences', these know-hows of enumeration, calculation, monitoring, evaluation, manage to be simultaneously modest and omniscient, limited yet apparently limitless in their application to problems as diverse as the appropriateness of a medical procedure and the viability of a university department. ${ }^{43}$

Indeed, today's proliferating metrics, and within the universities, today's bibliometrics, represent in a Foucauldian optic less anything unprecedented than a paradigm instance of a neoliberal, managerial technology. In order for an organisation to be audited, and the unchecked reign of its rent-seeking experts to be undercut or opened out, it must first be auditable. Yet many of the activities carried out in universities, welfare agencies, or hospitals look intrinsically qualitative affairs: face-to-face relations with patients, pedagogical work, or indeed the production of high-quality research within one or other highly-specialised field, closed to all but highly trained experts. What Rose calls "a new grid of visibilities" is then required ${ }^{44}$ if we are to perform the miracle of reversing Hegel and turning the qualitative back into the quantitative, while casting exogenous light upon hitherto-closed off, recondite specialisations. And different metrics - whether documenting numbers of calls per hour or patients treated, jobs sought per week or fortnight, student satisfaction, papers published, etc. - are there to perform just this miracle. Where previously no such possibility existed, metrics promise to document the hard numerical truths about the conduct of individuals across any range of activities, while leaving these individuals formally 'free' to pursue their tasks and enterprise them-

${ }^{41}$ We refer here to the prescient 1980 study by Stuart Burchell, Colin Clubb, Anthony Hopwood, John Hughes and Janin Nahapiet, "The Roles of Accounting in Organizations and Society," Accounting, Organizations and Society 5:1 (1980), 5-21. The practice of accounting, they already found, could "no longer be regarded as a mere collection of techniques for the assessment of individual economic magnitudes," exactly because it had begun to function "as a cohesive and influential mechanism for economic and social management" (ibid., 6). Accounting systems and measures, they noted, "are often used to articulate and promote particular interested positions and values," at ibid., 17. It is worth noting that these analysts hailed from the London Graduate School of Business Studies and Oxford Centre for Management Studies.

42 Ibid., 6.

43 “Governing 'Advanced' Liberal Democracies," 54.

${ }^{44}$ Ibid., 54; on bibliometrics as a means of commensurating the qualitatively different, see "Living with the H-Index," 363-364. 
selves. ${ }^{45}$ Armed with such metrics, meanwhile, managers and their decision-making prerogatives are liberated from the direct need to attend to or comprehend the on-theground concerns, specialised knowledges and responsibilities of their line workers - a thought we will return to in Part 3. They need now only survey the abstract 'quant-data' which, to echo Marx, 'manages for them,' increasingly enabled by the monitoring and metrical affordances of digital and web-based technologies. ${ }^{46}$ All the while, employees are brought through periodic performance assessments and attendant discourses to subjectivise these metrics as the numbers that 'count,' over and above whatever first-order expertise they have been trained to exercise.

On the one hand, if we now turn specifically towards bibliometrics and the neoliberal governance of tertiary education, it could be said that there is nothing new here: education and forms of accounting have long been inextricably linked. Indeed, Hoskin and Macve have shown this longstanding link in their historical analysis of accounting practices from antiquity onwards - including the influence of alphanumerics, and of 'secondary' forms of writing such as listings, ledgers and accounts: "[W]ith the invention of the academic mark and its behavioural counterpart, the merit-demerit system," different forms of examination and the numerical ranking of students have long been an essential component of the Western university. ${ }^{47}$ On the other hand, what bibliometrics now promise to enable, with all the seeming authority of quantitative measurements, is something genuinely novel, and specific to the neoliberal dispensation. This is an ongoing quantitative regimen of examination and ranking, but of the education professionals insofar as these professionals are also now expected to be, as well as teachers, professional researchers publishing online, citable journal articles in the sanctioned professional format, between $4-12,000$ words, plus or minus attendant notes. ${ }^{48}$ One need only scan electronically, count and compare the citations different people, papers, journals,

\footnotetext{
${ }_{45}$ As with the enterprising of the unemployed, governance in current 'developed' regimes prompts and requires the 'free' buy-in of modern citizens, emphasising their "participation, accountability, transparency, and human rights as basic elements in the management of society" ("Governance, Security and Technology," 113).

${ }^{46}$ Burchell, Clubb, Hopwood, Hughes and Nahapiet, "The Roles of Accounting," 17: "The powerful are helped to observe the less powerful, but not vice versa, as a rather particular mode of surveillance is established." This is a comparable asymmetry as that governing the harvesting of biometrics, as above.

${ }^{47}$ Keith W. Hoskin and Richard H. Macve, "Accounting and the Examination: A Genealogy of Disciplinary Power," Accounting Organizations and Society 11:2 (1986), 129.

${ }^{48}$ Let us flag here the evident danger which other authors have noted (see note 6 above): by singling out only what is countable about given processes or activities, neoliberal "metric power" inevitably abstracts from a good deal of what makes each distinctly what it is or was - like the proverbial man who will only look for his lost keys under the lamp, since that is the only place in the room where he can see. By seeking to apply such blunt measures, based on a series of assumptions formal enough to accommodate the metrical counting, rating and ranking of highly diverse activities, metrics introduce superficial numerical goals that actively then distort what they were ostensibly only concerned to measure, as academics and institutions reshape behaviour to meet exogenous requirements (what Power's The Audit Society, esp. 96-104, calls "rituals of verification" or "inspection," in his discussion of academic auditing since the 1990s). But this form of critique cannot be pursued further here.
} 
departments or entire institutions receive - the seemingly most innocuous or marginal features of scholarly labour. ${ }^{49}$

\section{Part 2: From the Bible to Bibliometrics, the Genealogy of Notes}

Yet how, then, are we to understand this specific form of bibliometrics as a neoliberal technology specifically aimed at governing forms of academic research, that specifically proposes to register and count the number of citations which given written texts, and thereby their human creators, receive over time? In order to address this question, we need to understand how this noting technology stands in relation to a different genealogy: that of previous forms of documentation and note-taking in the Western heritage. We will see then that the political functionality we have already glimpsed for bibliometrics in Part 1, and which we will duly analyse more closely in Part 3, is not entirely unprecedented. It carries forwards and transforms a much older genealogy tracing the surprisingly close but longstanding links between forms of Western note-taking and documentation, and forms of political subjectivation and control.

The texts that people write, and indeed the things that they have deemed worthy of noting down, have of course changed profoundly over time. These written artefacts have nevertheless always reflected, and in turn shaped the subjects who recorded or read them, and their specific intellectual, political and wider cultural contexts. In two invaluable articles, ${ }^{50}$ Roger J. Connors has thus argued that, in order to understand the different forms of Western note-taking up to the present, we need to keep these different cultural and rhetorical dimensions always in view:

The gradual formalization of written citation systems should not...blind us to their essentially rhetorical nature. Every formal structure implies a universe of meanings. Every formal structure declares allegiances and counter-allegiances. Every formal structure suggests the ethical and pathetic as well as the logical nature of a discourse [i.e. Aristotle's three means of persuasion]. The seemingly 'transparent' structures

\footnotetext{
${ }^{49}$ The rise of social media has also begun to 'count,' in the dissemination and reception of academic publications, in ways which fall outside of the purview of our analysis here. Some scholars and institutions now use platforms such as Twitter, Google+ and Facebook to "enhance and extend the impact of their articles and books," as well as using them as another means of rating and ranking scholarly activities (Lisa Blackman, "Social Media and the Politics of Small Data: Post-Publication Peer Review and Academic Value," Theory, Culture \& Society 33:4 (2016), 3-4). Blackman notes that "altmetrics" is presently emerging as a new, would-be hegemonic auditing standard "in this space," involving the process of "post-publication peer review," or "tracking publication afterlives" online-in terms of readers, tweets, shares, etc. She flags issues of scientific and scholarly integrity, the legal ambiguity of publishing rights, and the lengths (and excesses) of self-promotion thereby raised or solicited: "co-produced and entangled with relations of status, prestige, hierarchy and worth" in an increasingly overcrowded, web-enabled status marketplace (ibid., 6, 11).

${ }^{50}$ Robert J. Connors, "The Rhetoric of Citation Systems, Part I: The Development of Annotation Structures from the Renaissance to 1900," Rhetoric Review 17:1 (Autumn 1998), 6-48; and Robert J. Connors, "The Rhetoric of Citation Systems, Part II: Competing Epistemic Values," Rhetoric Review 17:2 (Spring 1999), 219245. We will be drawing closely on these two invaluable articles in the analysis that follows.
} 
used in formal citation systems have always been as much products and reflections of social and rhetorical realities as all other elements of discourse. ${ }^{51}$

At least five axes present themselves in such a rhetorical purview which we can use to analytically delineate the specificity of bibliometrics as a contemporary form of notation. Per Figure 2, these axes single out the ways that notation of different kinds are always: firstly, made by some particular subject (the who); secondly, directed at someone, whether oneself or others (the whom); thirdly, about some particular 'what' or subject deemed worthy of recording; fourthly, availing themselves of specific means - material or technological, as well as logical or rhetorical; and finally, recorded or published with some 'why' or end in mind (whether ethical, political, pious, playful or pedagogical).

\begin{tabular}{|c|c|c|c|c|c|}
\hline & who & To whom & about what & how & why \\
\hline $\begin{array}{l}\text { 1. Marginalia to } \\
\text { Torah, Bible, (in } \\
\text { renaissance) } \\
\text { classical texts }\end{array}$ & $\begin{array}{l}\text { Scribes, } \\
\text { commentator } \\
\text { s on sacral } \\
\text { text }\end{array}$ & $\begin{array}{l}\text { Readers } \\
\text { (posited as in } \\
\text { *need* of } \\
\text { interpretative } \\
\text { aid) }\end{array}$ & $\begin{array}{l}\text { Interpretive } \\
\text { clarification of } \\
\text { sacral text/s }\end{array}$ & $\begin{array}{l}\text { Written, then } \\
\text { typeset marginalia, } \\
\text { then marginal } \\
\text { print in others' } \\
\text { texts }\end{array}$ & $\begin{array}{l}\text { Political: censorship, control dissemination of meaning, } \\
\text { eliminate ambiguity, create uniform community of belief. }\end{array}$ \\
\hline 2. Self-writing & $\begin{array}{l}\text { Subject- } \\
\text { author }\end{array}$ & subject-author & $\begin{array}{l}\text { the self: desires, } \\
\text { beliefs, actions, } \\
\text { thoughts }\end{array}$ & $\begin{array}{l}\text { Memory notes in } \\
\text { own book/s: } \\
\text { written }\end{array}$ & $\begin{array}{l}\text { Ethical: to recall valued principles, to master unwanted } \\
\text { desires, to maintain consistency of behaviour, to aid } \\
\text { memory. }\end{array}$ \\
\hline $\begin{array}{l}\text { 3. Common- } \\
\text { places }\end{array}$ & $\begin{array}{l}\text { Subject- } \\
\text { reader- } \\
\text { student }\end{array}$ & $\begin{array}{l}\text { Subject- } \\
\text { reader-student }\end{array}$ & $\begin{array}{l}\text { Elegant } \\
\text { formulations on key } \\
\text { subjects }\end{array}$ & $\begin{array}{l}\text { Commonplace } \\
\text { books: written }\end{array}$ & $\begin{array}{l}\text { Intellectual: to aid memory, recall flowers of wit or } \\
\text { expression, shape style, shape self-presentation, recall key } \\
\text { points of others' discourses. }\end{array}$ \\
\hline $\begin{array}{l}\text { 4. Enlightenment } \\
\text { discursive notes } \\
\text { (also cross } \\
\text { references) }\end{array}$ & author & $\begin{array}{l}\text { Readers (to } \\
\text { evade censors) }\end{array}$ & $\begin{array}{l}\text { Controversial religious, } \\
\text { political, ethical, } \\
\text { philosophical, sexual } \\
\text { subjects }\end{array}$ & $\begin{array}{l}\text { Typeset: Discursive } \\
\text { notes posing as type } \\
1 \text {, but pushing and } \\
\text { evading censorship. }\end{array}$ & $\begin{array}{l}\text { Political and intellectual: to communicate contraband content, } \\
\text { despite censorship by political and religious orthodoxies. }\end{array}$ \\
\hline
\end{tabular}

Figure 2: Pre-Bibliometric Types of Western Note-Taking (Who, Whom, What, How, Why)

Today's bibliometrics are the heirs of three basic, prior kinds of note-taking from the classical, Judaeo-Christian and modern legacies (discursive-interpretative notes, aids to memory, and citational notes), and what can be identified as four lineages of such documentation. ${ }^{52}$

The first lineage of notes that emerges in the Western heritage are discursiveinterpretative in kind. Twenty-four hundred years old, they take the form of marginal notes containing Midrash of the Torah and homiletic texts, added by hand by the Hebrew scribes transcribing the sacred texts. ${ }^{53}$ The annotation form developed by these scribes consisted of a widely spaced original text, centrally placed and written in large letters, surrounded by smaller glossing text. In 1481, following the advent of printing, the first marginal annotations of this type appeared in print in a Venetian edition of

\footnotetext{
${ }^{51}$ Connors, "The Rhetoric of Citation Systems, Part I," 6-7.

52 Following Connors and Hauptman, and with a view to our specific concerns, we exclude here forms of directly administrative note-taking or inventorying, reaching back to some of the earliest forms of writing. ${ }^{53}$ Hauptman, Documentation, 14-15; "The Rhetoric of Citation Systems, Part I," 7-8.
} 
Horace with marginal commentaries by Acro and Porphyry (compare the Virgil text in Figure 3). ${ }^{54}$

Here as elsewhere throughout the genealogy of notational practices, a material cause (or how) underwrote the form these 'marginalia' took on. Their inclusion on the same pages as the source text served to save paper, and hence economise on costs. Nevertheless, this material form - with the original text as it were walled in on all four sides by interpretive additions - also eloquently betrays the telos or why of these discursiveinterpretative notes.

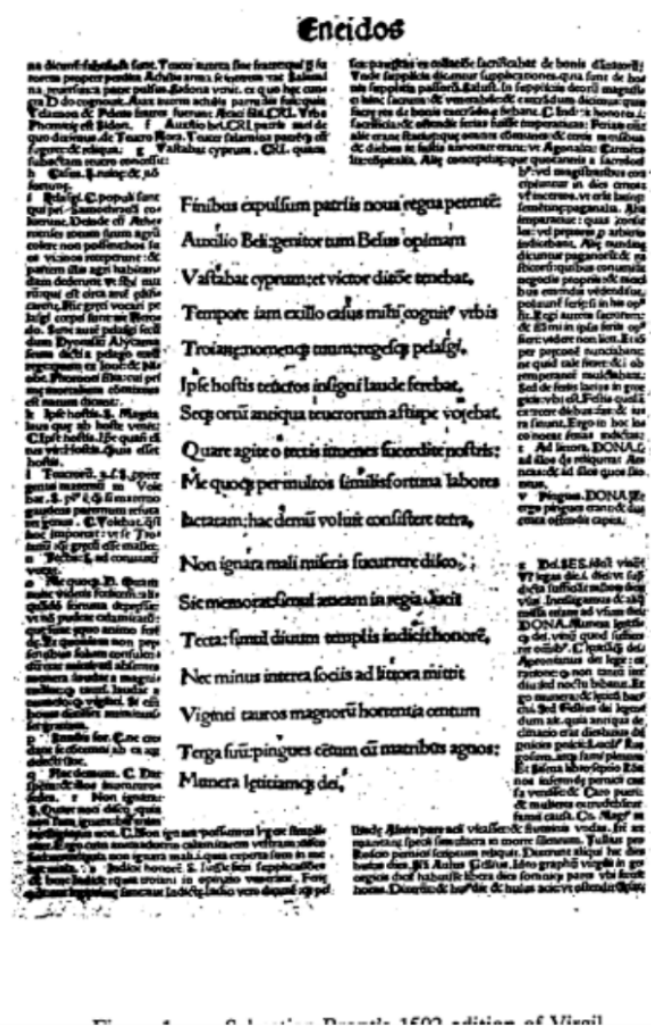

Figure 3: Humanist, Marginal Notes in a 1600 Edition of Virgil

As with the Hebrew Midrash, many of the earliest annotated texts in Christian Europe were editions of the Bible: a text of the highest religious and political significance. The goal of these notes, added to the source text with the imprimatur of sanctified Church authorities (the $w h o$ ), was to effectively hem in or control the interpretation of Holy Writ by its lay readers (the whom). Thus, for instance, the $13^{\text {th }}$ century Glossa Ordinaria encircled biblical verses with authorised marginal and interlinear glosses from theologians and teachers like Walafrid Strabo and Peter Lombard. ${ }^{55}$ The Reformation's appeal to sola scriptura called for new Bibles in the vernacular languages to enable the laity to read for themselves, freed from the mediations of the Papal Church. Nevertheless, far from removing marginal glossa, the Reformation instead gave rise to Bibles with Protestant "counter-glossa," evincing the same intentionality of hermeneutic control as their foes. Thus, the Coverdale Bible sponsored by Henry VIII (1535: Figure 4) inserted into the

\footnotetext{
54 “The Rhetoric of Citation Systems, Part I," 8-9.

55 Ibid., 15.
} 
margins of biblical verses a series of small pointing hands that, far from mere curios, served to indicate to the laity those passages which allowed for no 'private interpretation,' belonging hermeneutically to the Church of England. ${ }^{56}$

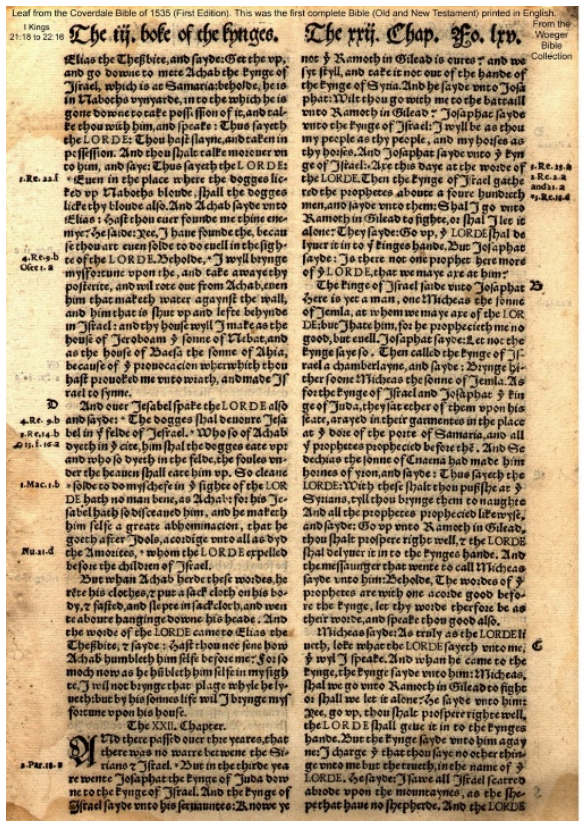

Figure 4: Coverdale Bible, with 'Pointers' to which Sayings are Off Hermeneutic Limits

With 1582 and the Rheims Bible (Figure 5 below), we arrive at a landmark text and date in the genealogy of Western notation: the birth both of endnotes, and also of the specifically citational notes which would assume such predominance in the professional academic writing of the 19th and 20th centuries. ${ }^{57}$ Endnotes, plus marginalia, are introduced for the first time at the end of biblical chapters in this Catholic text.

56 Ibid., 18-19.

57 Ibid., 19-23. 


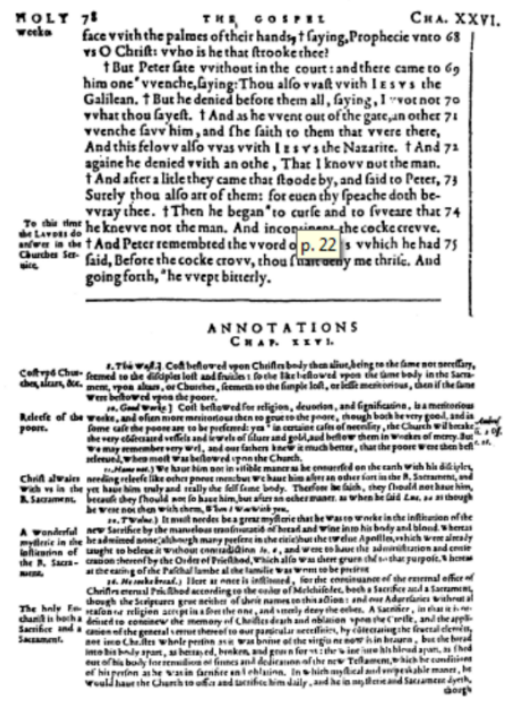

Figure 5: Page from the 1582 Rheims Bible, the Origin of Western Citational Notes

From the technical point of view, these endnotes served to reduce the clutter of pages that had been introduced by earlier, text-encircling marginal notes. Nevertheless, the same politics of annotation, one of hermeneutic control over the whom (lay readers), remained determinative. The Rheims Bible thus features discursive, interpretative notes appealing again to the authority of revered Catholic theologians from Ambrose to Augustine. Protestants are by contrast named as "the adversaries" or "hereticks," and we are served notice that these endnotes are expressly there to prevent readers following "their private judgement or the arrogant spirit of Sectaries." 58 It is in fact as servants of just this confessional-political mission that the Rheims Bible also featured the West's first citational notes. ${ }^{59}$ In the struggle against heresy, nothing less precise would any longer do: the good but easily-misled Catholic readers must from now on be directed to duly-sanctioned authorities by titles, editions, chapters and verses, leaving no documentary detail to choice (hairêsis) or chance.

The West's second, competing lineage of note-taking was approached by Michel Foucault in his last works on the care of the self in classical antiquity under the heading of "Self Writing." ${ }^{60}$ As Foucault's title suggests, here a quite different political or rather ethical intentionality is in play, compared to that underlying the biblical genesis of today's discursive and citational notes. The subject making the notes here (the who) is also their principal or sole intended addressee (the whom). Their content (the what) may come from samples of others' read or heard discourses, or from working over deeply-held philosophical or religious convictions. Yet one's notes, when one is engaged in producing such "hypomnemata" (aids to memory) need never be read by others: a fate that Mar-

\footnotetext{
${ }^{58}$ Ibid., 21.

${ }^{59}$ Ibid., 21-23.

${ }^{60}$ Michel Foucault, "Self Writing" [1994], in Ethics, Subjectivity, and Truth: The Essential Works of Michel Foucault, 1954-1984, Vol. 1, ed. Paul Rabinow (1997), 207-224; see also on this ancient practice, Pierre Hadot, The Inner Citadel: The Meditations of Marcus Aurelius [1992] (1998).
} 
cus Aurelius seems clearly to have intended for what we know as his Meditations. Ethical benefit is instead sought from the very act of recording different thoughts or sayings, and of having these written aids-to-memory "at hand" to shape one's life and choices at need. ${ }^{61}$ Thus, the Roman Stoic Epictetus enjoins his pupils, in the text that Arrian, his pupil, recorded as the opening of the Discourses: "let these thoughts be at your command [prokheiron] by night and day: write them, read them, talk of them, to yourself and to your neighbour..." 62

The lineage of "commonplace notebooks" belonging to the rhetorical tradition also falls squarely within this second, Western notational legacy. Here, while author and addressee, who and whom, are again the same individual, the why was less about reforming a person's entire conduct, as with the Stoic and Christian hypomnemata, so much as training the subject in the ability to recollect and elegantly express opinions about 'common' civil, political, ethical, or even natural and religious subjects. One would for instance enter elegant sentences or striking examples under the headings of the four cardinal virtues and the different vices. ${ }^{63}$ As Ann Moss' Printed Commonplace-Books and the Structuring of Renaissance Thought highlights, the locus classicus informing the continuing lineage of commonplacing into the early modern period comes from Seneca's Letters to Lucilius. In the $84^{\text {th }}$ letter, Seneca writes to his student that, in order to read productively:

We should imitate bees and we should keep in separate compartments whatever we have collected from our diverse reading, for things conserved separately keep better. Then, diligently applying all the resources of our native talent, we should mingle all the various nectars we have tasted, and turn them into a single sweet substance, in such a way that, even if it is apparent where it originated, it appears quite different from what it was in its original state. ${ }^{64}$

It is just such a practice, as Moss and others have shown, that forms the basis of the example- and sententia-thick essays of the early modern period: notably those of Michel de Montaigne and Francis Bacon. ${ }^{65}$ Such commonplacing was a preoccupation of early modern educational thinkers like Erasmus. Here, it was conceived as the means not simply to supplement memory but also to cultivate abundance (copia) and elegance of written and spoken language - as well as thereby, of course, to signal the subject's belonging to a classically and biblically educated elite, as later the use of citational notes will signal professional belonging. ${ }^{66}$ The philosopher Francis Bacon's epistolary ex-

\footnotetext{
${ }^{61}$ Foucault, "Self Writing," 220-221.

62 Epictetus, quoted in ibid., 209. As Foucault shows, this practice of self-writing survived antiquity and migrated into the monastic tradition. The Vita Antonii of Athanasius hence enjoins his charges, noting the Christian inflection, to: "[l]et this observation be a safeguard against sinning: let us each note and write down our actions and impulses of the soul as though we were to report them to each other...." (ibid., 207).

${ }^{63}$ See esp. Ann Moss, "Ancient and Medieval Places," chap. 1 in Printed Commonplace-Books and the Structuring of Renaissance Thought (1995).

${ }^{64}$ Seneca, Letters to Lucilius, 84, 5-6, cited at Moss, Printed Commonplace-Books, 11-12.

${ }^{65}$ See esp. William E. Engel, "Aphorism, Anecdote, and Anamnesis in Montaigne and Bacon," Montaigne Studies 1:1 (1989), 158-176.

${ }^{66}$ On Erasmus and commonplacing, see Printed Commonplace-Books, 102-115.
} 
change with the poet Fulke Greville, for instance, is given over to his proffering the younger man advice on note-taking at the beginning of his university career; ${ }^{67}$ a subject central also in his "A Letter and Discourse to Sir Henry Savile Touching Helps for the Intellectual Powers" and his "Second Letter to the Earl of Rutland." 68

What we might term a third 'counter-lineage' of occidental note-writing emerges nearly contemporaneously with the declining centrality both of the Bible within lettered European culture, and of the Renaissance practices of commonplacing. This tradition looks back in particular to Pierre Bayle, the sceptical dialectician whose Historical and Critical Dictionary, today little read, was amongst the most influential works of the $18^{\text {th }}$ century Enlightenment. ${ }^{69}$ Many of the pages of this remarkable Dictionary feature only a small amount of text on the alphabetised entries at the top of the folio columns. These scant entries are however accompanied by a far greater volume of discursive, footnoted "Remarks" (indicated by capital letters) beneath. For example, the entry on "Virgil" (compare Figure 6) has only 44 lines of text, plus some 1044 lines of discursive footnotes.

What makes the Baylean notes so singular, however, is less their quantity than their novel, subversive intentionality. If, in the forms of self-writing we have seen, it is a matter of drawing notes from other texts so the author can form themselves; and if, within the midrashic-biblical tradition, authorities had inserted interpretative notes as means to police authorised meaning, with Bayle the political functionality of the discursive note is inverted. Here, it becomes a means to evade theologico-political censorship and expand the knowledges and subjects available for readers' consideration. Bayle's most famous entry "David" thus involves a brief, pious exposition of the biblical stories concerning the Old Testament king. Bayle's notes, by contrast, criticise the plausibility of biblical claims: "it is somewhat strange that Saul did not know David, the day he slew Goliath...since that young man had played several times on the musical instruments for him...."70

\footnotetext{
${ }^{67}$ Francis Bacon, "Advice to Fulke Greville on his Studies," in Francis Bacon: The Major Works, ed. Brian Vickers (2002), 102-106.

${ }^{68}$ Francis Bacon, "A Letter and Discourse to Sir Henry Savile Touching Helps for the Intellectual Powers" and "Advice to the Earl of Rutland on his Travels" in ibid., 114-119, 69-80. Bacon himself seems to have at one point kept 28 commonplace books: "in one he jotted down any idea as it occurred to him, in another he copied as many of these reflections as time had shown to have some value, in a third he entered excerpts from his readings without order, and in a fourth excerpts and original ideas were arranged under heads [i.e. commonplaces]." Jacob Zeitlin "Commonplaces in Elizabethan Life and Letters," The Journal of English and Germanic Philology 19:1 (January 1920), 64.

${ }^{69}$ On Bayle, specifically his noting practices, see Documentation, 44-48; Anthony Grafton, The Footnote: A Curious History (1997), 191-215; Chuck Zerby, The Devil's Details: A History of Footnotes (2002), 66-78.

${ }^{70}$ Pierre Bayle, "David" [1697], in Historical and Critical Dictionary: Selections, ed. Richard H. Popkin (1991), 49, "C." On this entry and its subversive notes, with the political context, see Walter Rex, "Pierre Bayle: The Theology and Politics of the Article on David: Part I," Bibliothèque d'Humanisme et Renaissance 24:1 (1962), 168-189.
} 


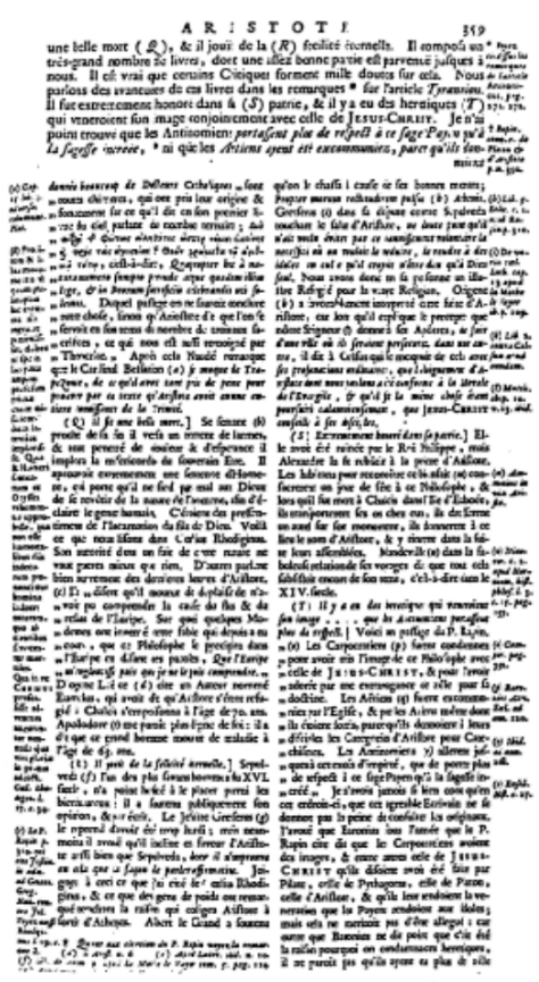

Figure 6: A Page from Bayle, the 'Devil' being in the Detailed, Sprawling Notes

They challenge the competence of biblical author/s:

if such a narrative as this should have been found in Thucydides... all the critics would unanimously conclude that the transcribers had transposed the pages, forgot something in one place, repeated something in another, or inserted some preposterous additions in the author's name. ${ }^{71}$

Bayle also questions the exemplary credentials of the biblical king himself, painting him instead as a lecher and a brigand: "to tell the truth, his conduct was very bad." 72 In the excitable words of one recent commentator, Bayle's notes "buzz with every pornographic interpretation of a biblical passage and every sexual anecdote about a philosopher or a scholar."73

With the advent of the modern university in the first decades of the $19^{\text {th }}$ century, a fourth notational lineage - the one in which academic professionals still largely operate today - was set to emerge. Citational notes, from this point onwards, took on both a new

\footnotetext{
${ }^{71}$ Bayle, "David," 49, “C."

72 Ibid., 51, "D."

${ }^{73}$ At Zerby, The Devil's Details, 71. We note also that Bayle laces his long notes with subversive crossreferences, leading the reader from notes to one entry to notes in another, and sometimes into contradictory termini. Likewise, in the Encyclopedia of Diderot and D'Alembert, which hymns Bayle, in a dedicated entry, Bayle's admirers borrow something of his form, as well as content. The entry "God," for instance, which is pious and conventional, closes with a link to "Demonstration," in which the epistemic bases for believing in the miracles and stories at the origin of revealed Christianity are scrupulously undermined. See Will Durant and Ariel Durant, The Age of Voltaire (1968), 644.
} 
prominence and a different scholarly why to those of prior practices of note-taking, whether sacred or sacrilegious. From instruments of churchly hermeneutic control or the means to forms of self-cultivation, notes now became shibboleths of a new community of note-takers and readers: that of secularised, professional scholars. Addressed by aspirant or established scholars (the who) to other professionals (the whom), notes in later modern academic writings "often sounded and looked like what they were: the secret handshake known only to members of the secret society, filled with the latinate citation jargon that had grown up since the Renaissance" (loc. cit., ibid., etc.). ${ }^{74}$ Their presence at the foot of pages, or trailing from the ends of chapters or learned monographs serves on the one hand to certify - a powerful means of persuasion - that the particular knowledge-claims proffered by the text are duly certified and traceable back to recognised proof texts or established authorities. ${ }^{75}$ On the other hand, they announce that their creator is no mere philosophe, litterateur, amateur or 'man of letters,' but a literate member of a select, credentialed professional status group. ${ }^{76}$

The year 1892, when the US Geological Survey published its Suggestions for the Preparation of Manuscripts, then marks, after 1582, a further 'red letter date' in the genealogy of today's bibliometrical dispensation. ${ }^{77}$ These Suggestions are the first published manual given over to how academic professionals should formally make citational references. By 1906, the first Chicago Manual of Style had appeared, featuring four pages of "Hints to Authors and Editors" of learned journals, with three pages devoted to "Footnotes."78

Different humanistic or scientific disciplines, indeed different journals within given subject fields, have negotiated differently the ensuing transition to the later modern citational dispensation. Generally speaking, the sciences have opted for the in-text Harvard referencing style. This notation sacrifices readability, where long lists of authors and dates end sentences, but efficiently marks dates of publication of research. As Connors notes, it thus well encapsulates and communicates the ethos of these cumulative, quickly-evolving research fields. ${ }^{79}$ Humanities outlets, by contrast, have mostly held on to foot- or endnotes, both to save the readability of the main text, and to keep open the possibility of discursive-interpretative notes: a last umbilical tying the later modern "disciplinary capture" of knowledge ${ }^{80}$ back to classical philology and biblical hermeneutics. 'In-between' disciplines in the social sciences, notably psychology, have experienced a 'science envy' which their evolving citational conventions, amongst other markers, allows us to trace. Whereas the first "List of References" in a psychological journal appeared in 1918, and many outlets continued to allow footnote citations until around

\footnotetext{
${ }^{74}$ Connors, “The Rhetoric of Citation Systems, Part 2," 222.

${ }^{75}$ See Grafton, The Footnote, 22-23.

${ }^{76}$ See on this point "The Rhetoric of Citation Systems, Part 1," 40-43.

77 Ibid., 43.

${ }^{78}$ Ibid., 43-45.

79 “The Rhetoric of Citation Systems, Part 2," 222-224.

80 See Robert Frodeman and Adam Briggle, Socrates Tenured: The Institutions of 21 st_Century Philosophy (2016), $73-75$.
} 
1950, after this time, psychological journals have opted for Harvard, with all its scientistic connotations. ${ }^{81}$

The bibliometrics of the first decades of the $21^{\text {st }}$ century, evidently, institute a new turn of the screw, predicated upon this later modern, citational, professionalising legacy - as well as the much longer-standing ties between discursive and citational notation and forms of political control. It is to the specific parameters of this new notational and governmental technology, and the forms of intellectual subjectivity it supposes and calls into being ${ }^{82}$, that we turn now.

\section{Part 3: Bibliometrics Reframed}

As a form of notation that presupposes pre-existing professional, disciplinary practices of citational referencing, bibliometrics are presented by their advocates as being as 'apolitical' as these citational notes themselves. Indeed, they are celebrated as, at last, proffering 'scientific' mathematical measures to adjudicate research quality more reliably than the in-house peer reviewing which they at once presuppose and increasingly supplant. All this new form of notation after all proposes is that, since we now can, we also should tally the references to the proper names of authors and article titles in 'donor' articles, leaving all of the established academic practices of peer review and publication ostensibly in place as before.

Nevertheless, if we look at bibliometrics now in the comparative light cast by our genealogy of the prior forms of notation in Part 2, we see that citation counting is predicated on an unprecedented three-fold abstraction in the history of Western notation. This treble abstraction both bespeaks and renders invisible new forms of power and control, more subtle and indirect but no less real than those characterising the biblical glossa and the theologico-political censorship still facing figures like Bayle and his admirers during the Age of Enlightenment. First, these metrics abstract from any and all content being conveyed in the 'donor text/s' about the cited text/s. It is enough that the 'recipient' text is cited in a 'donor' journal, whether critically, perfunctorily or in praise - so long as that journal's articles themselves are registered and counted by the relevant bibliometric index. Secondly, bibliometrics thus abstract completely from any direct engagement with or evaluation of the specific claims, epistemic virtues or contents of the referenced article itself. Each article now 'gets its significance back from the others,' as it were - for the notes that will attest to its merit and status are not its own. Thirdly, bibliometric citation counting therefore abstracts almost completely from any intentionality of either authors or readers of the donor or recipient articles. Whereas marginalia grew out of scribal transcription, and foot- and endnotes from the powers of the printing press, bibliometrics presupposes a new, this time automated, asubjective material medium: that of the internet. Uniquely in the history of notation, however, its medium or how, moreover, is also as it

\footnotetext{
81 “The Rhetoric of Citation Systems, Part 2," 228-232.

82 What Hall calls the "academic subjectivation machine," in Gary Hall, “\#Mysubjectivation," New Formations: A Journal of Culture/Theory/Politics 79 (2013), 89-92.
} 
were now the who making the notes: automatically and constantly, using algorithmic programming, while the human scholars whose labours they quantify sleep or write..$^{83}$

Alongside this new who, bibliometrics introduce a new principal whom into the history of noting. As we know from Part 1, this whom is none other than the neoliberal university manager. ${ }^{84}$ In place of the potentially misguided biblical laity, at permanent risk of being led astray; or of the note-taking subject wrestling with his passions or cultivating copia eloquentia; or, indeed, even of the humble scholar needing to be directed by due citations to the source texts appealed to by his/her colleagues - in place of all these prebibliometric notational addressees comes this new figure who, unlike any of his predecessors, need not understand (or potentially misunderstand) the first-order content across the range of disciplines that fall under his operational sway; and who need indeed open no text at all, as we have just seen, from the practitioners in these disciplines. They need instead only log in to one or other web-based platform that will proffer, almost instantaneously, the rank orderings of thousands of individuals and articles, and hundreds of journals. These rankings, to be sure, draw upon and reframe the collective labour of academics engaged in thousands of hours of peer reviewing. But their legibility, and their claim to quantitative authority, call upon no direct scholarly expertise of this managerial addressee's own - who indeed 'gets more for less,' the ultimate promise of neoliberal 'governing at a distance.' Taken up now by global university ranking agencies, as we opened by stressing, these novel notational technologies are thus rapidly becoming a reified universal, increasingly unchallenged tool of university governance, individual performance management, and finally academics' own sense of what it is that they are and do. ${ }^{85}$

For we also saw in Part 1 that the technologies of neoliberal governmentality indeed work by inculcating new understandings of their own values, actions and aims into the governed subjects themselves. It is a matter of prompting these subjects to govern and market themselves as entrepreneurial investors of their own "human capital." 86 The

\footnotetext{
83 This is also why, until such time as all printed books are uploaded online, only electronic journals, as against monographs or collections can count/be counted by several of the major bibliometric platforms.

${ }^{84}$ And via managers, the universities themselves. Weingart and Maasen ("Elite Through Rankings," 76) show for instance how, in Germany, the artificial category of the 'elite' university is propped up based on spurious ranking metrics. And much like the way in which academics are expected to regulate themselves within the terms of these arrangements, universities as "institutional selves" through the same "accounting and other managerial procedures" become "capable of steering themselves and others in most flexible ways, thereby turning themselves into what we call enterprising universities." See also "The Institutionalization of Rankings," 10.

${ }^{85}$ Compare "Living with the H-Index," 361-362.

${ }^{86}$ As we commented in note 35 above, in his 14 March 1979 lecture at the Collège de France, Foucault entered into a discussion of the notion of 'human capital,' considered both, along the line of classical economic analyses, as "the extension of economic analysis into a previously unexplored domain"; as well as, from the opposite angle, the extension of the idea of the human into the domain of the economic ("the possibility of giving a strictly economic interpretation of a whole domain previously thought to be non-economic"). Foucault notes a shift, within post-war liberal economic theories, from a concentration on "things or processes" to the "internal rationality" of forms of human behaviour, focused on the question of why people decide "to allot given scarce resources to this end rather than another." When economists start to define
} 
fundamental, as it were 'proto-managerial' promise of the panopticon thus remains operative: one in which the issue of whether anyone actually watches surveilled subjects in the panopticon is less important than the way that the observed or managed subjects are trained to observe and 'manage' themselves. ${ }^{87}$ And this, precisely, seems to us to be the most important and potentially insidious register of bibliometrical technologies, as well as that which a Foucauldian approach in particular allows us to bring to needed critical visibility. ${ }^{88}$ To be sure, we no longer have to deal in bibliometrics with the direct priestly or political censorship which we have seen governed how and which discursive and citational notes were penned and published until the $18^{\text {th }}$ century. Like biopower itself, bibliometrics enunciate no direct injunctions or prohibitions. Rather, through their sheer proliferation, and through the mouths and judgements of their managerial addressees, they promote within academics themselves (their secondary, ultimate whom) new conceptions and measures of 'success' profoundly distant from any of the traditional or modern-postcritical, endogenous understandings of intellectual labour.

In one sense, therefore, it can be accurately said that the bibliometrics redouble, although not reverse, the economy of visibility at work in the Benthamite panopticon. For what matters here is not simply that the subjects themselves, or their 'outputs,' are visible and counted - although this very much also remains the case. To exert their full subjectivising effects, the bibliometrical counts and rankings must also themselves become increasingly visible to citational academic subjects. They must be there, as they increasingly are, as soon as an academic logs in to a university homepage via their personalised 'dashboards'; as soon as they visit a site like academia.edu, increasingly important in fostering research connections and keeping up with their field; or indeed as soon as they, pursuing their labours, so much as open the websites of journals which they must read if they are to contribute to scholarship (see Figure 7).

capital in terms of the individual's 'income streams' and 'wages,' in the form of "that which makes a future income possible, this income being a wage," then one sees that "it is a capital which in practical terms is inseparable from the person who possesses it." Hence this form of capital is "the set of investments we have made at the level of man himself" and humans begin to be considered, in a new way, as calculable present and prospective earnings streams that one can bank upon and insure against. Marx's alienated worker of the 19th century thus became in the latter half of the 20th century "an enterprise for himself" and as such we see "[a]n economy made up of enterprise-units, a society made up of enterprise-units" (The Birth of Biopolitics, 215-237).

${ }^{87}$ We refer here of course to the classic analysis of the panopticon in Foucault, Discipline and Punish, 199207.

${ }^{88}$ See “Living with the H-Index," 364. 


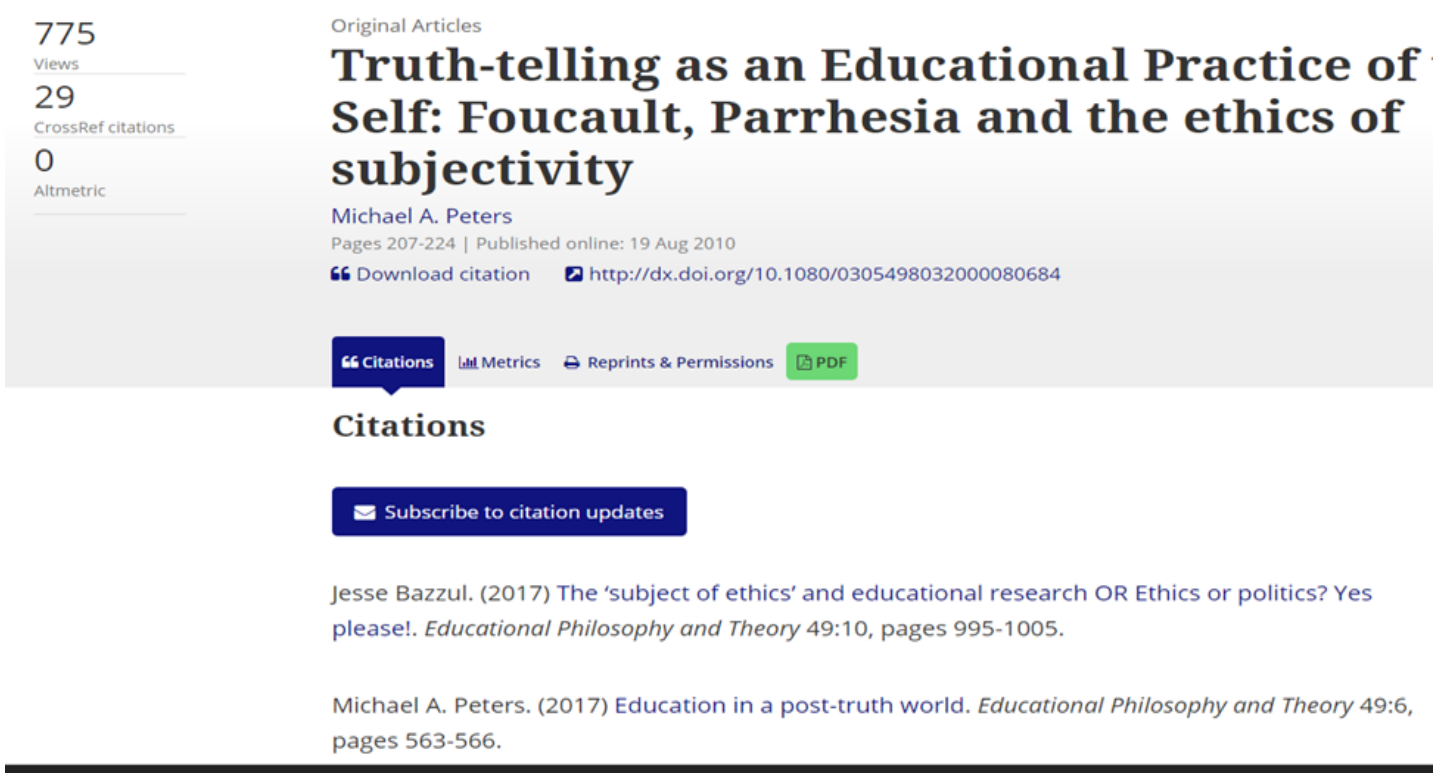

Figure 7: Metric Creep: Views, Crossref Citations, Citation Updates on a Journal Homepage

For it is by way of this visibility, as well as in their growing ubiquity in the discourse of managers and colleagues, that metrical assessments of their fields are internalised by academics, reshaping their sense of what is worth thinking, writing, reading, or doing. Let us say then, looking back to Part 2, that these 'hyper-visibilised' bibliometrics also function as in effect 'para-hypomnêmata.' They are reminders to selves, recalling them to what counts, as in the Stoic or Christian traditions of self-writing. But the who, as we have seen, is not the noting subject, but the web-based affordances without which they increasingly cannot do their work, which now have taken on the role of automatically reminding them, several times every day, of where they sit in the global research ranking order; that there is such an order, increasingly sanctioned by universities and journals themselves; and that everything they write will be, has been, and is being constantly rated in these terms. 


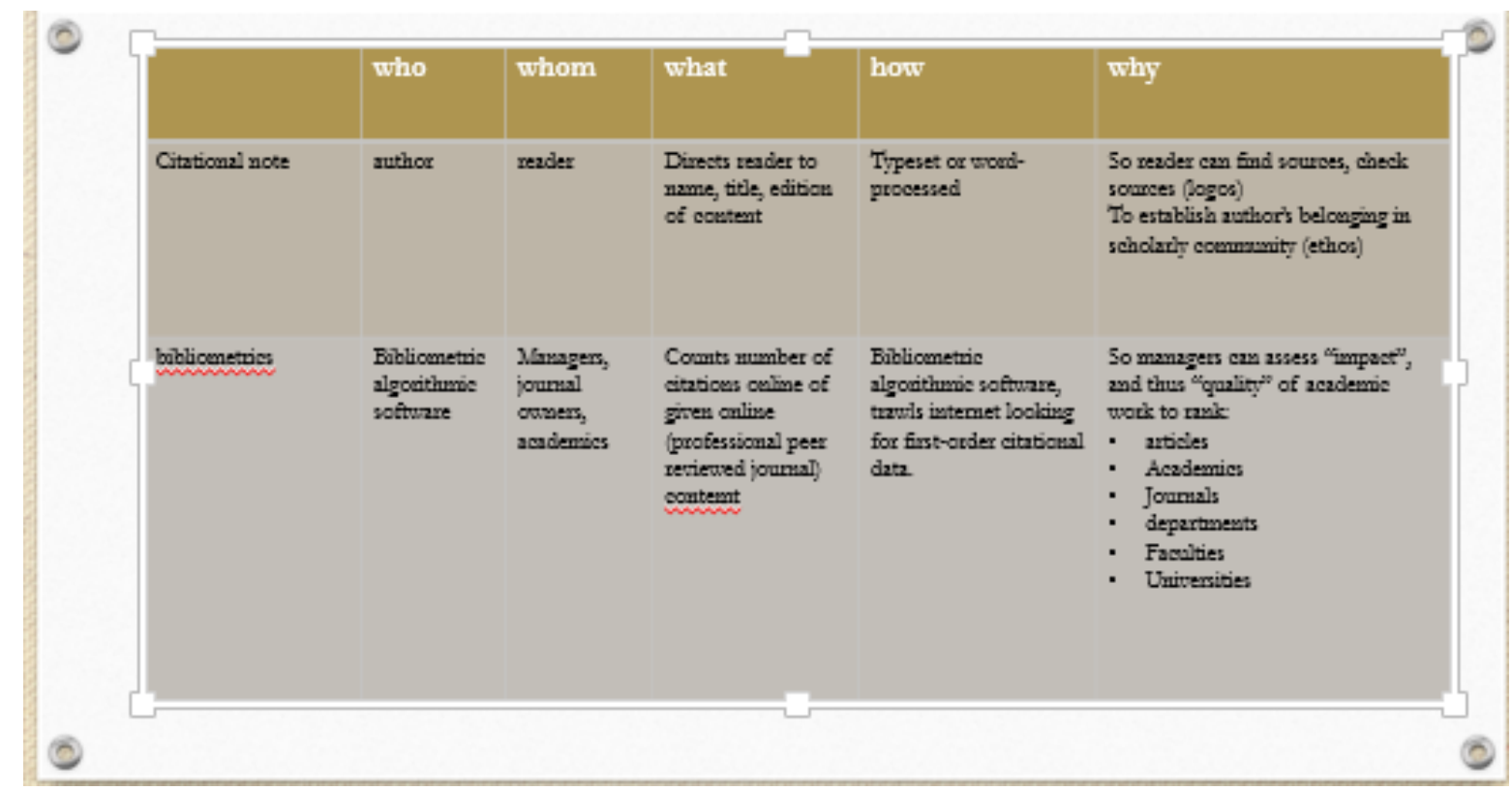

Figure 8: Bibliometric versus Citational Noting (Who, Whom, What, How, Why)

The "bibliometric academic subject," as we might call someone who has wholly internalised the new bibliometrical dispensation, would then be a profoundly new kind of intellectual subject, relative to their predecessors in the multifarious histories of the life of the mind. They would be a figure who pre-eminently writes; who reads so they can write and must write so they can survive in the increasingly competitive markets for tenured or fixed-term academic work. ${ }^{89}$ They would be someone who will write only for, and increasingly only read in certain bibliometrically ordained journals - which will attract massive amounts of traffic, and need to institute increasingly prohibitive rates of acceptance and rejection. They would be someone who, independent of what they write upon - from progressive politics to the human genome - will have internalised the notion that 'good' or 'rigorous' or 'professional' or 'serious' work is always 'impact-ful' work: and that this 'impact' is authoritatively measured by the bibliometrical rankings which they need only go online to recall to mind. They would be someone who will always be aware of their status as a ranked competitor with their contemporaries. They may increasingly indeed have ready to hand (prokheiron) not only their own h-, i- and sundry citational indexes, but those of potential rivals for positions, promotions, grants or honours. They will above all be a subject acutely dependent for their sense of professional (and thus wider) status on the opinions and citations of others. This citational value, delivered back to them through the oracular portals of increasingly traffic-lightcoded (red, orange, and green) journal and personal ranking sites, will tell them sufficiently the truth about their status, what is to be done and what to be ignored.

The aim of this essay in the history of the present has been only to understand the genealogical lineages and comparative singularities of contemporary bibliometrics as a notational means for assessing academic research. We have tried also to render visible

\footnotetext{
${ }^{89}$ On the way this dispensation plays upon, indeed commodifies older models of authorship and "originality," see Hall, “\#Mysubjectivation," esp. 96-97.
} 
the wider cultural and political dimensions and stakes of this proliferating phenomenon. Readers will form their own opinions concerning the bibliometric avatar depicted in the previous paragraph, a counter-factual projection with heuristic intent more than an actual portrait. Certainly, our analysis shows how the burgeoning reign of bibliometrics is pushing contemporary academia far away from Pierre Bayle - "the Mozart of the footnote" $^{\prime 90}$ - and his republic of letters, let alone Bayle's reworking of discursive and citational notes into a sprawling arsenal to provoke his contemporaries to challenge authority and think anew.

\section{References}

"Poor Citation Practices Are a Form of Academic Self-Harm in the Humanities and Social Sciences," Medium.com, https://medium.com/advice-and-help-in-authoring-a-phd-or-nonfiction/poor-citation-practices-are-a-form-of-academic-self-harm-in-the-humanities-andsocial-sciences-2cddf250b3c2, accessed October 2017.

Bacon, Francis, "Advice to the Earl of Rutland on his Travels," "Advice to Fulke Greville on his Studies," and "A Letter and Discourse to Sir Henry Savile Touching Helps for the Intellectual Powers" in Francis Bacon: The Major Works, ed. Brian Vickers, 69-80, 102-106, 114-119. Oxford: Oxford University Press, 2002.

Baneyx, Audrey, "'Publish or Perish' as Citation Metrics Used to Analyze Scientific Output in the Humanities: International Case Studies in Economics, Geography, Social Sciences, Philosophy, and History," Archivum Immunologiae et Therapiae Experimentalis 56 (2008), 363-371. https://doi.org/10.1007/s00005-008-0043-0

Bayle, Pierre, "David" [1697], in Historical and Critical Dictionary: Selections, ed. Richard H. Popkin, 45-63. Indianapolis, IN: Hackett Publishing, 1991.

Beer, David, Metric Power. London: Palgrave Macmillan, 2016.

Blackman, Lisa, "Social Media and the Politics of Small Data: Post-Publication Peer Review and Academic Value," Theory, Culture \& Society 33:4 (2016), 3-26. https://doi.org/10.1177/0263276415590002

Borgman, Christine L., "Editor's Introduction," in Scholarly Communications and Bibliometrics, ed. Christine L. Borgman, 10-27. Newbury Park, CA: Sage, 1990.

Brembs, Björn, Katherine Button and Marcus Munafò, “Deep Impact: Unintended Consequences of Journal Rank," Frontiers in Human Neuroscience, 24 June 2013. https://doi.org/10.3389/fnhum.2013.00291

Burchell, Graham, "Liberal Government and Techniques of the Self," in Foucault and Political Reason, eds. Andrew Barry, Thomas Osborne and Nikolas Rose, 19-36. London: UCL Press, 1996.

Burchell, Stuart, Colin Clubb, Anthony Hopwood, John Hughes and Janin Nahapiet, "The Roles of Accounting in Organizations and Society," Accounting, Organizations and Society 5:1 (1980), 5-21. https://doi.org/10.1016/0361-3682(80)90017-3

Burrows, Roger, "Living with the H-Index," The Sociological Review 60:2 (2012), 355-372. https://doi.org/10.1111/j.1467-954X.2012.02077.x

90 The Devil's Details, 77. 
Connors, Robert J., "The Rhetoric of Citation Systems, Part I: The Development of Annotation Structures from the Renaissance to 1900," Rhetoric Review 17:1 (Autumn 1998), 6-48. https://doi.org/10.1080/07350199809359230

Connors, Robert J., “The Rhetoric of Citation Systems, Part II: Competing Epistemic Values,” Rhetoric Review 17: 2 (Spring 1999), 219-245. https://doi.org/10.1080/07350199909359242

Crawford, Kate, Jessa Lingel and Tero Karppi, “Our Metrics, Ourselves: A Hundred Years of Selftracking from the Weight Scale to the Wrist Wearable Device," European Journal of Cultural Studies 18:4/5 (2015), 479-496. https://doi.org/10.1177/1367549415584857

Dean, Mitchell, Governmentality: Power and Rule in Modern Society. London: Sage, 1999.

Durant, Will and Ariel Durant, The Age of Voltaire. New York, NY: Simon \& Schuster, 1968.

Engel, William E., "Aphorism, Anecdote, and Anamnesis in Montaigne and Bacon," Montaigne Studies 1:1 (1989), 158-176. https://doi.org/10.15122/isbn.978-2-406-06999-7

Foucault, Michel, Discipline and Punish: The Birth of the Prison [1975]. London: Vintage, 1995.

Foucault, Michel, "Self Writing" [1994] in Ethics, Subjectivity, and Truth: The Essential Works of Michel Foucault, 1954-1984, Vol. 1, ed. Paul Rabinow, 207-222. New York, NY: The New Press, 1997.

Foucault, Michel, The Will to Knowledge: The History of Sexuality, Vol. 1 [1976]. London: Penguin, 1998.

Foucault, Michel, The Birth of Biopolitics: Lectures at the Collège de France, 1978-1979 [2004]. New York, NY: Palgrave Macmillan, 2008.

Frank, Thomas, One Market Under God: Extreme Capitalism, Market Populism and the End of Economic Democracy. London: Vintage, 2002.

Frodeman, Robert and Adam Briggle, Socrates Tenured: The Institutions of $21^{\text {st_Century Philoso- }}$ phy. London: Rowman \& Littlefield, 2016.

Grafton, Anthony, The Footnote: A Curious History. Cambridge, MA: Harvard University Press, 1997.

Hadot, Pierre, The Inner Citadel: The Meditations of Marcus Aurelius [1992]. Harvard, MA: Harvard University Press, 1998.

Hall, Gary, “\#Mysubjectivation," New Formations: A Journal of Culture/Theory/Politics 79 (2013), 83-102.

Harzing, Anne-Wil, "Citation Analysis Across Disciplines: The Impact of Different Data Sources and Citation Metrics," Harzing.com: Research in International Management, http://harzing.com/publications/white-papers/citation-analysis-across-disciplines, accessed October 2017.

Hauptman, Robert, Documentation: A History and Critique of Attribution, Commentary, Glosses, Marginalia, Notes, Bibliographies, Works-Cited Lists, and Citation Indexing and Analysis. Jefferson, NC: McFarland, 2008.

Hicks, Diana, Paul Wouters, Ludo Waltman, Sarah de Rijcke and Ismael Rafols, “Bibliometrics: The Leiden Manifesto for Research Metrics," Nature 520:7548 (22 April 2015), 429431. https://doi.org/10.1038/520429a

Hoskin, Keith W. and Richard H. Macve, "Accounting and the Examination: A Genealogy of Disciplinary Power," Accounting Organizations and Society 11:2 (1986), 105-136. https://doi.org/10.1016/0361-3682(86)90027-9 
Jones, Phil, "Altmetrics and Research Assessment: How Not to Let History Repeat Itself," The Scholarly Kitchen, 1 September 2015, https://scholarlykitchen.sspnet.org/2015/09/01/altmetrics-and-research-assessment-hownot-to-let-history-repeat-itself, accessed October 2017.

Lane, Julia, “Let's Make Science Metrics More Scientific,” Nature 464:1267 (25 March 2010), 488-489. https://doi.org/10.1038/464488a

Lemke, Thomas, "'The Birth of Bio-Politics': Michel Foucault's Lecture at the Collège de France on Neo-Liberal Governmentality," Economy and Society 30:2 (2001), 190-207. https://doi.org/10.1080/03085140120042271

Lo, William Y.W., University Rankings: Implications for Higher Education in Taiwan. Singapore: Springer, 2014.

Locke, William, "The Institutionalization of Rankings: Managing Status Anxiety in an Increasingly Marketized Environment," in University Rankings: Theoretical Basis, Methodology and Impacts on Global Higher Education, eds. Jung C. Shin, Robert K. Toutkoushian and Ulrich Teichler, 201-228. Dordrecht: Springer, 2011.

Macilwain, Colin, "Halt the Avalanche of Performance Metrics," Nature 500:7462 (14 August 2013), 255. https://doi.org/10.1038/500255a

Moss, Ann, Printed Commonplace-Books and the Structuring of Renaissance Thought. Oxford: Oxford University Press, 1995.

Power, Michael, The Audit Society: Rituals of Verification. Oxford: Oxford University Press, 1997.

Pritchard, Alan, "Statistical Bibliography or Bibliometrics," Journal of Documentation 25:4 (1969), 348-349.

Pugliese, Joseph, Biometrics: Bodies, Technologies, Biopolitics. London: Routledge, 2010.

Rex, Walter, "Pierre Bayle: The Theology and Politics of the Article on David: Part I," Bibliothèque d'Humanisme et Renaissance 24:1 (1962), 168-189.

Rose, Nikolas, "Governing 'Advanced' Liberal Democracies," in Foucault and Political Reason, eds. Andrew Barry, Thomas Osborne and Nikolas Rose, 37-64. London: UCL Press, 1996.

van Wesel, Maarten, "Evaluation by Citation: Trends in Publication Behaviour, Evaluation Criteria, and the Striving for High Impact Publications," Science and Engineering Ethics 22:1 (2016), 199-225. https://doi.org/10.1007/s11948-015-9638-0

Weingart, Peter and Sabine Maasen, "Elite Though Rankings - The Emergence of the Enterprising University," in The Changing Governance of the Sciences: The Advent of Research Evaluation Systems, eds. Richard Whitley and Jochen Gläser, 75-99. Dordrecht: Springer, 2007.

Zeitlin, Jacob, "Commonplaces in Elizabethan Life and Letters," The Journal of English and Germanic Philology 19:1 (January 1920), 47-65.

Zerby, Chuck, The Devil's Detail: A History of Footnotes. New York, NY: Simon \& Schuster, 2002.

Zureik, Elia and Karen Hindle, "Governance, Security and Technology: The Case of Biometrics," Studies in Political Economy 73:1 (2004), 113-137.

https://doi.org/10.1080/19187033.2004.11675154 
Author info

Matthew Sharpe, PhD Associate Professor

Faculty of Arts and Education

Deakin University

Australia

matthew.sharpe@deakin.edu.au

Kirk Turner

PhD candidate

Faculty of Arts and Education

Deakin University

Australia

kirk.turner@deakin.edu.au 